НАУКОВИЙ ВІСНИК

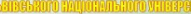

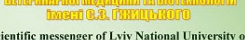

cientific messenger of Lviv National University
Veterinary Medicine and Biotechnologites

tum

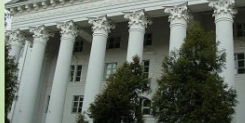

Том 21 № 91

2019
Науковий вісник Дьвівського національного університету ветеринарної медицини та біотехнодогій імені С.3. Гжицького. Серія: Сільськогосподарські науки

\author{
Scientific Messenger of Lviv National University \\ of Veterinary Medicine and Biotechnologies. \\ Series: Agricultural sciences
}

ISSN 2519-2698 print

https://nvlvet.com.ua/index.php/agriculture

doi: 10.32718/nvlvet-a9111

UDC 636.2.088.636.084

\title{
Probiotic feed supplement "PROGAL" in feeding the milking cows
}

\author{
B.S. Denkovich, Y.I. Pivtorak, N.M. Gordiychuk
}

Stepan Gzhytskyi National University of Veterinary Medicine and Biotechnologies Lviv, Ukraine

Article info

Received 10.09.2019

Received in revised form 10.10.2019

Accepted 11.10.2019

Stepan Gzhytskyi National University of Veterinary Medicine and Biotechnologies Lviv,

Pekarska Str., 50, Lviv,

79010, Ukraine.

Tel.: +38-050-522-86-23

E-mail:yaroslavpivtorak@gmail.com
Denkovich, B.S., Pivtorak, Y.I., \& Gordiychuk, N.M. (2019). Probiotic feed supplement "PROGAL" in feeding the milking cows. Scientific Messenger of Lviv National University of Veterinary Medicine and Biotechnologies. Series: Agricultural sciences, 21(91), 65-70. doi: 10.32718/nvlveta9111

Full-fledged feeding of milking cows, based on scientifically based standards, is the key to realizing their genetic potential for productivity, preserving health, normalizing reproductive capacity, as well as the rational use of fodder resources and the proper payment of feed. Nowadays, the situation regarding the standardization of cattle feeding in the world and domestic, both in scientific and industrial practice, has changed radically, which requires a significant revision of the traditional provisions on the organization of full feeding of cows, especially high-productive ones. At the same time, the conceptual requirements for the organization of standardized nutrition and full feeding of dairy cattle should be based on the generalization of the world experience of the animal's need for energy, nutrients and biologically active substances, taking into account age and level of productivity, conditions of keeping with special emphasis on quality and products. In conditions of intensive milk production, in order to ensure high productivity and at the same time to maintain the health of animals, it is impossible to do it without the use of fodder of a natural substance, which should include additives with a probiotic effect. One of these is the "PROGAL" feed additive, which contains a probiotic component: Laktobacilus casei strain (CM 1759), a potentiating component is maltodextrin, a fructo-oligosaccharide, and is a probiotic additive for ruminants. High dairy productivity requires constant monitoring of metabolism, animal health, early diagnosis and timely treatment and prevention. The whole process of metabolism takes place in the digestive tract and is transmitted to the cells of the body through blood. This explains the relevance of the study of biochemical processes in rumination. The basis of the research is the task of optimizing the normalized feeding of real cows due to the use in the diet of probiotic supplement "PROGAL" on the background of a semi-concentrated juicy silage-hay type feeding. On the basis of scientific-economic (90 days) experiment, to determine its influence on the processes of digestion in the rumen, milk productivity and quality indicators of milk and to conclude on the optimal amount of it in the diet. The studies were conducted on Simmental cows in the conditions of the "PchanyDenkovych" farm in the Zhydachiv district of Lviv region. It was found that feeding of the diet with feed supplements "PROGAL" aided to improve the intensity of metabolic processes in the body of cows, in particular in the rumen. Possible growth of amylo- and cellulosolytic and proteolytic bacteria was found, which ensured their enzyme activity and caused intensive hydrolysis of feed carbohydrates, resulting in an increase in LFA as precursors to milk fat. A positive result was obtained with respect to the level of dairy productivity of the cows of the experimental groups in comparison with the control group on the average daily milk yield, which is 1.0-2.3 kg, or 4.4-9.7\% more. There was a steady upward trend in fat content in milk by $0.05 \%$ and protein by $0.02-0.04 \%$, which indicates an improvement in its quality. Consequently, the studies conducted concerning the estimation of the productive action of bio supplement "PROGAL" on milking productivity of cows and quality indicators of milk, gives reason to confirm the feasibility of its use in the structure of the diet when feeding cows. The optimal dose of compound feed is $10 \mathrm{~g} /$ day, the maximum dose can be no more than $15 \mathrm{~g} /$ day. No adverse effects of "PROGAL" supplement on the overall functional status of cows were found.

Key words: "PROGAL" supplementation, active cows, milk productivity, microflora, feeding, nutrition, biochemical processes, scar, diet structure, type of feeding. 


\title{
Пробіотична кормова біодобавка "ПРОГАЛ" в годівлі дійних корів
}

\author{
Б.С. Денькович, Я.І. Півторак, Н.М. Гордійчук
}

Львівський національний університет ветеринарної медицини та біотехнологій імені С.З. Гжицького, м. Львів, Україна

Повноцінна годівля дійних корів, яка базується на науково обтрунтованих нормативах, є запорукою реалізації їхнього генетичного потенціалу продуктивності, збереження здоров'я, нормалізації відтворної здатності, а також раціонального використання кормових ресурсів і належної оплати корму продукцією. Нині ситуація стосовно нормування годівлі худоби у світовій і вітчизняній як науковій, так і у виробничій практиці докорінно змінилася, щуо вимагає суттєвого перегляду традииійних положень з організацї повночінної годівлі корів, особливо високопродуктивних. При иьому концептуальними вимогами щьодо організації нормованого живлення і повноцінної годівлі молочної худоби повинно будуватись на основі узагальнення світового досвіду потреби тварин в енергії, поживних і біологічно активних речовин з урахуванням віку і рівня продуктивності, умов утримання та експлуатачї з особливим акцентом на якість і біобезпеку продукції. В умовах інтенсивного виробництва молока, щзоб забезпечити високу продуктивність і при иьому зберегти здоров'я тварин, неможливо обійтись без застосування кормових засобів природної субстаниї, до яких варто зарахувати добавки з пробіотичною дією. До однієї із таких належить кормова добавка “ПРОГАЛ”, яка містить пробіотичний компонент: Laktobacilus casei штам (СМ 1759), потениіюючий компонент - мальтодекстрин, фрукто-олігосахарид, і належить до пробіотичної добавки для жуйних. Висока молочна продуктивність потребує постійного моніторингу за станом обміну речовин, здоров'ям тварин, ранньою діагностикою і своєчасним проведенням лікувально-профілактичних заходів. Весь прочес обміну речовин відбувається у травному тракті та передається до клітин організму через кров. Це пояснює актуальність вивчення біохімічних прочесів у рубиі жуйних. В основу проведення досліджень покладено завдання оптимізації нормованої годівлі дійних корів за рахунок використання в складі раціону пробіодобавки “ПРОГАЛ” на фоні напівконцентратного соковитосилосно-сінажного типу годівлі. На основі проведення науково-господарського (90 діб) досліду, встановити ї̈ вплив на процеси травлення в рубиі, молочну продуктивність і якісні показники молока та зробити висновок щодо оптимальної ї кількості у раціоні. Дослідження проводили на коровах симентальської породи в умовах фермерського господарства “Пчани-Денькович” Жидачівського району Львівської області. Встановлено, щуо згодовування в складі раціону пробіодобавки “ПРОГАЛ” сприяло поліпшенню інтенсивності обмінних прочесів в організмі корів, зокрема у рубиі. Виявлено, вірогідне зростання аміло- $і$ иелюлозолітичних, а також протеолітичних бактерій, щцо забезпечило їх ензимну активність та зумовило інтенсивний гідроліз вуглеводів кормів, у результаті чого спостерігається зростання ЛЖК, як попередників молочного жиру. Отримано позитивний результат ияодо рівня молочної продуктивності корів дослідних груп порівняно з контрольною групою за середньодобовими надоями, щзо на 1,0-2,3 кг, або 4,4-9,7\% більше. Спостерігалася стабільна тенденція до зростання вмісту жиру у молоиі на 0,05\%, та білка на 0,02-0,04\%, щчо вказує на поліпшення його якості. Отже, проведені дослідження, за оцінкою продуктивної дї про біодобавки “ПРОГАЛ” на молочну продуктивність корів та якісні показники молока дають підставу твердити про доиільність ї̈ використання у структурі раціону при годівлі корів. Оптимальною дозою введення до складу комбікорму є 10 г гол./обу, максимальна доза може бути не більше 15 г гол./добу. Побічного негативного впливу пробіодобавки “ПРОГАЛ” на загальний функиіональний стан корів не виявлено.

Ключові слова: пробіодобавка “ПРОГАЛ”, дійні корови, молочна продуктивність, мікрофлора, годівля, живлення, біохімічні прочеси, рубець, структура рачіону, тип годівлі.

\section{Вступ}

Інтенсифікація розвитку такої галузі тваринництва, як молочна спрямована на пошук шляхів найбільш ефективного використання кормів, що за вартістю займають 55-60\% і більше на виробництво молока (Shcherbatyj et al., 2017; Kharko et al., 2017). У зв'язку з цим для збереження поголів’я, підвищення продуктивності та рентабельності його виробництва фахівці працюють над вирішенням проблеми повноцінної збалансованої годівлі дійних корів. Запорукою досягнення максимуму коефіцієнту корисної дії кормів і кормових добавок $є$ створення такої системи живлення, яка забезепечувала б найбільш оптимальні умови для інтенсифікації процесів обміну речовин. Однією $з$ основних передумов підвищення як молочної продуктивності, так і профілактики розладів травлення $\epsilon$ застосування пробіотичних кормових добавок, що являють собою низькомолекулярні вуглеводи, з'єднані між собою $\beta$-глікозидним зв'язком і можуть розщеплюватися у верхньому відділі шлункового тракту виключно нормальною мікрофлорою та $є$ поживою, яка стимулює іiї розвиток. В кінцевому підсумку поліпшується загальний функціональний стан організму тварин, підвищується продуктивність
(Lourens-Hattingh \& Viljoen, 2001; LeBlanc, 2010; Kandyba et al, 2012; Czaplicka et al, 2014).

Багаторічний досвід застосування пробіотиків i праці багатьох вчених з різних країн світу, підтверджують їх позитивний вплив. Проте результати досліджень часто відрізняються, а інколи є навіть суперечливими. Ці відмінності можуть залежати від багатьох факторів, таких як умови навколишнього середовища, стадії лактації, типу годівлі корів, структури раціону, дозу введення біодобавок, способів їх згодовування. Це обумовлює необхідність перевіряти продуктивну дію окремо взятих пробіотичних добавок на організм тварин в конкретних умовах тваринницьких підприємств. При цьому варто зазначити, що одним із актуальних напрямків підвищення ефективності засвоєння поживних речовин кормів є додаткове введення в структуру раціонів пробіотичних кормових добавок. До однієї із таких належить пробіокормодобавка "ПРОГАЛ".

У зв'язку з цим в основу наших досліджень покладено завдання оптимізації процесу годівлі дійних корів симентальської породи за рахунок використання у раціонах пробіокормодобавки "ПРОГАЛ" і встановлення іiї впливу на рубцеву ферментацію та молочну продуктивність за найоптимальнішої дози введення. 


\section{Матеріал і методи досліджень}

В основу досліджень покладено завдання оптимізації процесу годівлі високопродуктивних корів симентальської породи за рахунок використання в складі раціону пробіокормодобавки “ПРОГАЛ”. Наукововиробничий дослід тривалістю три місяці проводився у фермерському господарстві "Пчани-Денькович" Жидачівського району Львівської області за схемою, яка наведена у (табл. 1).

\section{Таблиця 1}

Схема науково-виробничого досліду, $\mathrm{n}=10$

\begin{tabular}{lc}
\hline \multicolumn{1}{c}{ Групи } & Особливості годівлі \\
\hline & Основний раціон (ОР) - сіно злаково- \\
1 - контрольна & бобове $-15 \%$, силос кукур. $-35 \%$, \\
& концентрати $-31 \%$, премікс $-1 \%$ \\
2 - дослідна & ОР + “ПРОГАЛ” -6 г гол/добу \\
3 - дослідна & ОР + “ПРОГАЛ” -10 г гол/добу \\
4 - дослідна & ОР + “ПРОГАЛ” -15 г гол/добу \\
\hline
\end{tabular}

Проби молока відбиралися в кінці кожного місяця протягом останніх двох суміжних днів дослідного періоду. Вихід молока, вміст в ньому жиру, білка, лактози та кількості соматичних клітин визначали за допомогою Milcoscan i Fosomatic.

На 30-, 50- і 70-ту добу досліду, через дві години після годівлі за допомогою зонду від 4-ох корів з кожної групи брали зразки вмісту рубця, у якому визначали загальний і білковий азот (за Кельдалем), азот аміаку (за Конвеєм), ЛЖК-в апараті Маркгама, pH- за допомогою іонометра СВ-74, а також амілолітичну, целюлозолітичну та протеолітичну активності (Vlizlo et al., 2012).

Статистичну обробку отриманих результатів досліджень проводили за допомогою загальноприйнятих методів варіаційної статистики 3 оцінкою (М), його похибки (m) і розрахунками вірогідності різниць за методом Стюдента 3 використанням програмного забезпечення "Microsoft Excel 2003".

Таблиця 2

Показники популяції мікроорганімів середовища рубця піддослідних корів $(\mathrm{M} \pm \mathrm{m}, \mathrm{n}=5)$

\section{Результати та їх обговорення}

У процесі досліджень в годівлі корів використовували корми, які вироблялися безпосередньо у господарстві, і за період досліду (90 діб) піддослідні корови всіх груп споживали практично однакову їх кількість, поживність відповідно становила 1692 кг корм. од. та 227,7 кг перетравного протеїну.

В процесі проведення експеременту на дійних коровах тварини споживали корми господарського виробництва 3 введенням у структуру комбікорму пробіотичної кормової добавки “ПРОГАЛ” в динаміці 6-10-15 г гол./добу, з метою визначення оптимальної дози згодовування.

Загалом, варто зазначити використання у раціонах піддослідних тварин пробіокормодобавки "ПРОГАЛ" по-різному позначалось на низці годівельних параметрів, зокрема, позитивно вплинуло на інтенсивність обмінних процесів в організмі корів, а звідси й на їх молочну продуктивність.

Про інтенсивний перебіг обмінних процесів свідчить перерозподіл чисельності мікроорганімів, які забезпечують засвоєння основних поживних речовин кормів раціону (табл. 2).

Єфективність використання кормів тваринами, зокрема жуйними, великою мірою залежить від характеру рубцевої ферментації. Важливим фактором, що визначає інтенсивність руменального бродіння, $\epsilon$ величина $\mathrm{pH}$, яка у піддослідних корів коливалась в межах оптимуму $(6,82-6,98)$ і практично була на рівні контрольної групи. Що стосується концентрації бактерій, то нами виявлено вірогідне зростання їхньої чисельності, зокрема, амілолітичних та целюлозолітичних бактерій, кількісна перевага (третя і четверта група) порівняно 3 контрольною відповідно складає $23,1-23,7$ та 27,8-29,2\% (P < 0,001). Аналогічна картина спостерігається за кількістю протеолітичних бактерій. Підвищений рівень наведених популяцій мікроорганізмів у руменальному середовищі рубця корів дослідних груп вказує на інтенсифікацію процесів поділу й розмноження клітин бактерій, їх росту, i, як наслідок, супроводжується накопичення в останньому сирої мікробіальної маси.

\begin{tabular}{lrrr}
\hline \multicolumn{1}{c}{ Показники } & \multicolumn{2}{c}{ Групи тварин } \\
\cline { 2 - 4 } & контрольна 1 & \multicolumn{2}{c}{ дослідні } \\
\cline { 3 - 4 } Мікроорганізми млн/мг: & & 2 & 4 \\
-амілолітичні & $9,97 \pm 0,16$ & $11,35 \pm 0,23$ & $12,27 \pm 0,27 * * *$ \\
-целюлозолітичні & $8,85 \pm 0,28$ & $11,21 \pm 0,39$ & $11,31 \pm 0,37 * * *$ \\
-протеолітичні & $3,69 \pm 0,17$ & $4,17 \pm 0,37$ & $4,21 \pm 0,38$ \\
рН & $6,80 \pm 0,01$ & $6,82 \pm 0,02$ & $6,96 \pm 0,03 * * *$ \\
Сира біомаса бактерій, мг/100 мк & $993 \pm 21,3$ & $1047 \pm 24,5$ & $1233 \pm 25,3 * * *$ \\
Ензимна активність мікрофлори : & & $4,33 \pm 0,38$ \\
-амілолітична, тис. умов. амілоліт. од. & $381 \pm 13,7$ & $1257 \pm 25,7 * * *$ \\
-целюлозолітична, \% & $15,23 \pm 1,21$ & $19,36 \pm 1,29$ & $20,53 \pm 1,20$ \\
-протеолітична, мекв. трозин, в 100 мл/хв & $3,76 \pm 0,19$ & $3,84 \pm 0,20$ & $3,87 \pm 0,27$ \\
ЛЖК, ммоль $/ 100$ мл & $9,73 \pm 0,27$ & $10,63 \pm 0,33$ & $11,63 \pm 0,35 * *$ \\
\hline
\end{tabular}

Примітка: у цій та наступних таблицях ріниці вірогідності порівняно з контролем: * $\mathrm{P}<0,05 ; * * \mathrm{P}<0,01 ; * * * \mathrm{P}<0,001$ 
За аналогією, стосовно змін чисельності рубцевої біоти у тварин дослідних груп цю закономірність встановлено і у випадку з їх ензимною активністю, що обумовило інтенсивний гідроліз вуглеводів кормів у результаті чого спостерігається вірогідне зростання (на 9,2-19,5\%; Р < 0,01) кількості ЛЖК. Адже відомо, що леткі жирні кислоти: оцтова, пропіонова масляна, слугують головним джерелом метаболічної енергії і після всмоктування використовуються в організмі лактуючих корів як попередники молочного жиру (Ibatulin et al, 2015).

Однією із ключових ланок обміну речовин в організмі жуйних, яка дає оцінити ефективність годівлі тварин за дії досліджуваного фактора $\epsilon$ фізіологобіохімічні показники вмісту рубця (табл. 3).

\section{Таблиця 3}

Показники азотового і вуглеводного обміну у вмісті рубця піддослідних корів $(\mathrm{M} \pm \mathrm{m}, \mathrm{n}=5)$

\begin{tabular}{lrrr}
\hline & & \multicolumn{2}{c}{ Групи корів } \\
\cline { 2 - 4 } \multicolumn{1}{c}{ Показники } & контрольна & \multicolumn{2}{c}{ дослідні } \\
\cline { 2 - 4 } & 1 & $84,50 \pm 0,71 * * *$ & $85,73 \pm 0,72 * * *$ \\
\hline Загальний азот, мг \% & $79,56 \pm 0,67$ & $85,90 \pm 0,72 * * *$ & $24,13 \pm 0,80$ \\
Залишковий азот, мг \% & $20,87 \pm 0,83$ & $23,51 \pm 0,81$ & $61,60 \pm 3,67$ \\
Білковий азот, мг \% & $58,69 \pm 3,73$ & $60,99 \pm 3,75$ & $38,81 \pm 2,86$ \\
Азот аміаку, мг \% & $38,73 \pm 2,85$ & $38,78 \pm 2,87$ & $3,95 \pm 0,92$ \\
Сума цукрів, мг \% & $3,25 \pm 0,21$ & $3,93 \pm 0,42$ & $38,75 \pm 2,88$ \\
Лактат, ммоль & $7,5 \pm 0,12$ & $5,3 \pm 0,15 * * *$ & $4,7 \pm 0,14 * * *$ \\
\hline
\end{tabular}

За результатами досліджень спостерігається наступна картина: у вмісті рубця корів дослідних груп встановлено вірогідне зростання загального і білкового азоту відповідно на 6,2-8,0 і 3,9-4,9\% (P < 0,001) порівняно з контрольною групою. Зростання концентрації загального та білкового азоту вказує на інтенсивну утилізацію аміаку мікрофлорою та поліпшення умов іiі життєдіяльності. Так, за вмістом аміаку у вмісті рубця тварин дослідних груп виявлено його зменшення, що підтверджує позитивний вплив досліджуваного фактору на процеси, які відбуваються в руменальному середовищі.

Щодо обміну в рубці піддослідних корів фосфатів, причетних до синтетичних та енергетичних процесів біологічного середовища за умов нашого досліду, відстежується наступне (табл. 4). Так, концентрація загального кислоторозчинного Фосфору вмісту рубця корів дослідних груп переважає аналог контрольних на 29,7-29,9\% (Р < 0,001). Стосовно переваги органічного фосфору дослідних груп над контрольною, то цей показник становить 24,3-31,4\%. Аналогічна тенденція спостерігається і у перевазі Фосфору РНК і ДНК над контрольною групою. Порівнюючи різницю за перерахованими фракціями фосфатів у вмісті рубця корів дослідних груп, варто підкреслити очевидні переваги реакцій гліколізу і процесів синтезу над такими корів контрольної групи (Vovk et al., 2002; Vojtovych, 2008; Polulix, 2012).

\section{Таблиця 4}

Концентрація фосфорних сполук у вмістимому рубця та крові піддослідних корів $(\mathrm{M} \pm \mathrm{m}, \mathrm{n}=5)$, ммоль/л

\begin{tabular}{|c|c|c|c|c|}
\hline \multirow{3}{*}{ Показники } & \multicolumn{4}{|c|}{ Групи корів } \\
\hline & \multirow{2}{*}{ контрольна 1} & \multicolumn{3}{|c|}{ дослідні } \\
\hline & & 2 & 3 & 4 \\
\hline \multicolumn{5}{|c|}{ рубець } \\
\hline \multicolumn{5}{|l|}{ Фосфор: } \\
\hline -загальний кислоторозчинний & $3,54 \pm 0,17$ & $10,53 \pm 0,18^{* * *}$ & $10,57 \pm 0,18 * * *$ & $10,60 \pm 0,19 * * *$ \\
\hline -неорганічний & $7,19 \pm 0,06$ & $7,36 \pm 0,05$ & $7,43 \pm 0,09$ & $7,37 \pm 0,13$ \\
\hline -органічний & $2,55 \pm 0,12$ & $3,17 \pm 0,19$ & $3,24 \pm 0,18$ & $3,35 \pm 0,89$ \\
\hline РНК & $605,9 \pm 18,3$ & $673,3 \pm 16,5$ & $679,3 \pm 16,7$ & $685,0 \pm 21,3$ \\
\hline ДНК & $392,9 \pm 20,1$ & $429,4 \pm 13,4$ & $433,1 \pm 19,3$ & $435,4 \pm 18,6$ \\
\hline \multicolumn{5}{|c|}{ кров } \\
\hline \multicolumn{5}{|l|}{ Фосфор: } \\
\hline -загальний кислоторозчинний & $2,55 \pm 0,06$ & $2,89 \pm 0,03 * * *$ & $2,91 \pm 0,03 * * *$ & $2,92 \pm 0,04 * * *$ \\
\hline -неорганічний & $1,49 \pm 0,02$ & $1,58 \pm 0,02$ & $1,66 \pm 0,01 * * *$ & $1,67 \pm 0,01 * * *$ \\
\hline -органічний & $1,06 \pm 0,03$ & $1,33 \pm 0,04$ & $1,25 \pm 0,04$ & $1,24 \pm 0,04$ \\
\hline РHK & $608,9 \pm 3,26$ & $641,7 \pm 4,51 * * *$ & $667,5 \pm 5,3^{* * *}$ & $661,7 \pm 5,4^{* * *}$ \\
\hline ДНК & $267,0 \pm 6,18$ & $282,6 \pm 10,43$ & $315,3 \pm 11,2 * *$ & $318,6 \pm 11,3^{* *}$ \\
\hline
\end{tabular}

Згодовування коровам в складі раціону пробіокормодобавки “ПРОГАЛ” суттєво позначилося і на рівні (в межах фізіологічної норми) вмісту фосфатів у крові тварин (табл. 4).

Зокрема, кількість загального кислоторозчинного Фосфору в крові корів дослідних груп переважає ана- логічний показник контрольної на $11,3-14,5 \%$ (P $<0,001)$, відповідно неорганічного - 6,0-12,1\% i органічного - на 25,5-17,9\%. На тлі представленого у міжгруповому порівнянні спостерігали також вищу на 5,4-9,6 i 5,8-19,3\% концентрацію Фосфору РНК і ДНК відповідно. Така тенденція є підтвердженням 
наростання процесів анаболізму в організмі тварин дослідних груп або свідченням інтенсифікації окисного фосфорелювання, тобто акумулювання енергії, що можна розцінювати як позитив впливу досліджуваного фактора на загальний функціональний стан організму тварин.

\section{Таблиця 5}

Молочна продуктивність та фізико-хімічні показники молока піддослідних корів, $(\mathrm{M} \pm \mathrm{m}, \mathrm{n}=10)$

\begin{tabular}{lcccc}
\hline \multirow{2}{*}{\multicolumn{1}{c}{ Поканики }} & \multicolumn{4}{c}{ Групи корів } \\
\cline { 2 - 5 } & контрольна 1 & \multicolumn{3}{c}{ дослідні } \\
\cline { 3 - 5 } & & & 3 & 4 \\
\hline Середньодобовий надій молока : & $21,5 \pm 0,44$ & $22,5 \pm 0,46$ & $23,8 \pm 0,51^{* *}$ & $23,0 \pm 0,51^{*}$ \\
натуральної жирності, кг & $24,6 \pm 0,52$ & $26,2 \pm 0,55^{*}$ & $28,1 \pm 0,56^{* * *}$ & $27,1 \pm 0,56^{* *}$ \\
базисної жирності, кг & $3,89 \pm 0,07$ & $3,96 \pm 0,08$ & $4,02 \pm 0,09$ & $4,00 \pm 0,09$ \\
Вміст в молоці, \%: жиру & $3,27 \pm 0,02$ & $3,29 \pm 0,03$ & $3,31 \pm 0,01$ & $3,30 \pm 0,02$ \\
білка & $4,94 \pm 0,07$ & $5,09 \pm 0,13$ & $5,10 \pm 0,12$ & $5,18 \pm 0,13$ \\
лактози & $1027 \pm 2,03$ & $1029 \pm 1,93$ & $1029 \pm 1,93$ & $1030 \pm 1,92$ \\
Густина, г/см ${ }^{2}$ & $11,51 \pm 0,07$ & $11,71 \pm 0,08$ & $11,75 \pm 0,07$ & $11,73 \pm 0,07$ \\
СЗМ3 - сухий знежирений & & & \\
молочний залишок, \% & & &
\end{tabular}

Молочна продуктивність та фізико-хімічні показники молока піддослідних корів за обліковий період наведено у (табл. 5). Середньодобовий надій натурального молока корів дослідних групп переважав контрольну группу тварин на 4,7-10,7\% (P <0,01$0,001)$ i базисного - відповідно на $6,5-11,4 \%$ ( $<0,05-0,001)$. Відзначено підвищення рівня СЗМЗ на $2,1 \%$, а також тенденцію до зростання вмісту жиру, загального білка та лактози відповідно на 3,$3 ; 1,2$ та $3,2 \%$, і як наслідок - густини молока корів дослідних груп, що вказує на поліпшення його якості та дає підставу твердити про доцільність використання пробіотичної кормової добавки “ПРОГАЛ” у годівлі дійних корів.

\section{Висновки}

Проведені дослідження за оцінкою продуктивності дії пробіотичної кормової добавки "ПРОГАЛ" на фізіолого-біохімічні показники, загальний функціональний стан організму дійних корів, а також молочну продуктивність, дають підставу твердити про доцільність ії використання в структурі раціону за однотипової годівлі.

Оптимальною дозою введення в склад комбікорму вважаємо 10 г гол./добу, максимальна доза може бути не більше ніж 15 г гол./добу. При цьому необхідно наголосити, що нами не відмічено побічного негативного впливу кормової добавки на загальний функціональний стан корів.

Подальші дослідження будуть спрямовані на оцінку якісних показників молока і виготовлених молочних продуктів за використання пробіокормодобавки “ПРОГАЛ" у різних за типом годівлі раціонах як зимового, так і літнього періодів. Передбачено також проведення досліджень на племінному молодняку і нетелях великої рогатої худоби.

\section{References}

Czaplicka, M., Puchajda, Z., \& Pawlak M. (2014). Efektywność stosowania droźdźy Saccharomyces cerevisiae w źywieniu krów mlecznych [Efficacy of Sac- charomyces cerevisiae yeast in feeding dairy cows]. Roczniki Naukowe Polskiego Towarzystwa Zootechnicznego, 10(4), 69-75. http://ptz.icm.edu.pl/download/2014/tom_10_4/VI_Cz aplicka.pdf (in Polska).

Ibatulin, I.I., Melnyk, Y.F., \& Otchenashko, V.V. (2015). Praktykum z hodivli silskohospodarskykh tvaryn: Navch. Posibnyk. Zh.: PP "Ruta" (in Ukrainian).

Kandyba, V.M., Ibatulin, I.I., \& Kostenko, V.I. (2012). Teoria i praktyka normovanoi hodivli velykoi rohatoi khudoby: Monohraphia (in Ukrainian).

Kharko, M.V., Denkovich, B.S., Pivtorak, Y.I., Naumyuk, A.S., Petryshak, R.A., Holodyuk, Y.P. (2017). Milk yield and metabolic processes in cows during the usage of the biosprint drug in the diet structure. Scientific Messenger LNUVMB, 19(79), 122-126. doi: $10.15421 /$ nvlvet7924.

LeBlanc, S. (2010). Monitoring metabolic health of dairy cattle in the transition period. J. Reprod Dev, 56, 2935. https://www.ncbi.nlm.nih.gov/pubmed/20629214.

Lourens-Hattingh, A., \& Viljoen, B.C. (2001). Growth and survival of a probiotic yeast in dairy products. Food Res. Int, 34(9), 791-796. doi: 10.1016/S09639969(01)00085-0.

Polulix, M.I. (2012). Metabolizm azotovyx spoluk u rubci dijnyx koriv za vykorystannya u godivli standartoyi ta eksperymentalnoyi bilkovo- vitaminno-mineralnoyi dobavky (BVMD). Zb. Nauk. Pracz VNAU, 4(62), 45-49 (in Ukrainian).

Shcherbatyj, Z.Y., Bodnar, P.V., \& Kropyvka, Y.G. (2017). Milk productivity and reproductive ability of ukrainian black-spotted dairy breed cows of different type of constitution. Scientific Messenger LNUVMBT named after S.Z. Gzhytskyj, 19(74), 182-187. doi: $10.15421 /$ nvlvet7440.

Vlizlo, V.V., Fedoruk, R.S., \& Ratych, I.B. (2012). Laboratorni metody doslidzhen u biologiyi, tvarynnycztvi ta veterynarnij medycyni: dovidnyk. Lviv, Spolom (in Ukrainian).

Vojtovych, N.G. (2008). Produktyvnist ta funkcionalna aktyvnist rubcya koriv pry zastosuvanni vysokobilkovyx kormiv i mineralnyx dobavok. Avtoreferat dysertaciyi na zdobuttya naukovogo 
stupenya kandydata silskogospodarskyx nauk. Kyiv (in Ukrainian).

Vovk, Ya.S., Vrydnyk, B.F., Vojtovych, N.G. ta in. (2002). Obmin rechovyn u rubci ta produktyvnist vidgodivelnyx bychkiv na foni riznoyi struktury sokovytoyi chastyny sylosno- koreneplidnokoncentratnogo racionu. Peredgirne ta girske zemlerobstvo i tvarynnycztvo, 44, 127-131 ( in Ukrainian). 